\title{
The Sources of Unemployment in Lesotho
}

\author{
${\text { Moeti Damane }{ }^{1} \text {, Lira P. Sekantsi }}^{2}$ \\ ${ }^{1}$ Research Department, Central Bank of Lesotho, Maseru, Lesotho \\ ${ }^{2}$ National Payment System Division, Central Bank of Lesotho, Maseru, Lesotho \\ Email: *damane.moeti@gmail.com, skantsy@gmail.com
}

How to cite this paper: Damane, M. and Sekantsi, L.P. (2018) The Sources of Unemployment in Lesotho. Modern Economy, 9, 937-965.

https://doi.org/10.4236/me.2018.95060

Received: March 22, 2018

Accepted: May 13, 2018

Published: May 16, 2018

Copyright ( 2018 by authors and Scientific Research Publishing Inc. This work is licensed under the Creative Commons Attribution International License (CC BY 4.0).

http://creativecommons.org/licenses/by/4.0/

\section{c) (i) Open Access}

\begin{abstract}
Lesotho's unemployment, poverty and income inequality and other social ills remain pervasive in the face of non-inclusive growth. Using structural vector autoregressive framework and annual time series data spanning from 1980 to 2014, this paper investigates the sources of the high unemployment in Lesotho, a small landlocked developing country whose currency is pegged to that of South Africa. The impulse response functions, forecast error variance decomposition and historical decomposition jointly revealed that unemployment dynamics in Lesotho largely emanate from shocks to employment, unemployment itself, productivity, real wages and inflation. The importance of positive shocks to employment and unemployment itself in explaining unemployment variations decline over time while the importance of positive shocks to productivity, real wages and inflation grow with time. In light of this, Lesotho's government should promote private sector development, diversify the economy's markets and invest in human and physical capital development with a view to increase employment.
\end{abstract}

\section{Keywords}

Unemployment, SVAR, Impulse Response Functions, Forecast Error Variance Decomposition, Historical Decomposition, Lesotho

\section{Introduction}

In recent years, business cycle research has devoted much attention to understanding the patterns of unemployment dynamics. The net changes of unemployment dynamics shape the adjustment of unemployment and provide a useful indicator of the economic situation [1]. This is because a high magnitude of unemployment dynamics could signal labour market deficiencies and/or rigidities, which ultimately positively impact upon poverty and income inequality and other social ills, on the one hand. On the other hand, high unemployment could 
potentially be a source of economic uncertainty. The issue of high unemployment has been of great concern to economic practitioners, policy-makers in governments and private sectors, academicians and international organisations both in developed and developing countries alike. In this regard, it has been a standing topic in the political debate for decades. Lesotho is not an exception in this case as the country has endured persistently high unemployment rates ranging between 23 percent and 28 percent over the past 10 years. The country has also experienced a high and widespread prevalence of poverty coupled with high income inequality in the face of non-inclusive growth. This has been due to, inter alia, labour market deficiencies, undiversified domestic markets and a relatively small private sector which resulted in large proportions of Lesotho's labour force seeking employment in the neighbouring country South Africa.

The objective of this paper is to investigate the patterns of unemployment in Lesotho not only with a view of contributing to the general body of knowledge on causes of unemployment in developing countries that are landlocked and of which the national currency is pegged to that of a highly dominant trading partner but also to offer a more nuanced understanding of the factors that drive unemployment in Lesotho as this will better inform policy decision-making in the country. To this end, the paper employs a structural vector autoregressive (SVAR) model and identifies variable shocks that are widely considered important in the explanation of labour market fluctuations. These shocks include productivity shocks, real wage shocks, inflation shocks and labour market shocks.

The subsequent parts of the paper are structured as follows: Section 2 provides a brief account of Lesotho's economy and unemployment dynamics. Section 3 gives the review of relevant theoretical and empirical literature. Section 4 presents the econometric methodology. Section 5 provides detailed analysis of the empirical results. The last section offers some concluding remarks together with policy recommendations.

\section{An Overview of Lesotho's Economy and Unemployment Dynamics}

Lesotho is a small and mostly mountainous country that is largely rural with a population of approximately 2 million people. It is completely enveloped by South Africa and through its membership in the Common Monetary Area $(\mathrm{CMA})^{1}$ its currency; the Loti (plural Maloti), is pegged at par to the South African Rand. Apart from CMA membership, the country is also a member of Southern African Customs Union (SACU) ${ }^{2}$ and Southern African Development Community (SADC). The country is not only one of the poorest in Southern Africa; but it is also one of the most unequal in the world. It has an open economy that is traditionally focused on trade. Textiles, water and diamonds are its main exports and its main trading partners are South Africa and the United States ${ }^{1}$ Other CMA member countries are Namibia and Swaziland.

${ }^{2}$ Other SACU member countries are Botswana, South Africa and Swaziland, Namibia. 
(US); with the former being its main trading partner. The national head count poverty rate was 57.1 percent in the fiscal year 2010/11 according to the 2010/11 household survey. This figure was virtually unchanged from the 2002/03 household survey. The level of inequality as measured by the Gini coefficient increased from 0.51 to 0.53 between 2002/03 and 2010/11. The main driver of growth in the country is government spending. Public spending in the 2014/15 financial year rose to about 63.1 percent of Gross Domestic Product (GDP) from 44.4 percent of GDP registered in the 2004/05 financial year [2].

The terms and conditions of employment in Lesotho are governed by the Lesotho's Labour Code Order of 1992 and its subsequent amendments. The Labour Code regulates terms of employment and conditions for worker health, safety, and welfare. It law permits union organization. The Labour Court and the Labour Court of Appeal are the key judiciary entities dealing with labour disputes. In addition, the Labour Code Amendment Act of 2000 established the Directorate of Industrial Dispute Prevention and Resolution (DDPR), which is a semi-autonomous labour tribunal independent of the government, political parties, trade unions, employers and employers' organizations. Lesotho National Development Corporation (LNDC) is another key institution that deals with labour disputes especially those arising from the manufacturing sector. The function of LNDC in this realm is to bring parties together before any formal process is set in motion. For example, LNDC intervenes in strikes and tries to reconcile workers and employers. When this informal process fails, the more formal process of the DDPR can be engaged which can consist of conciliation and arbitration.

The labour market of Lesotho is characterized by a low employment-toworking age population ratio. The government is the main employer in the formal sector of the domestic economy while the largest informal employer is the manufacturing sector. However, high levels of unemployment has led to increased number of the economically active being employed in South Africa; the main destination for Lesotho's migrant labour. In 2008, Lesotho had a total of $1,461,763$ persons that were eligible for entry into the labour market. In the same year, 42.3 percent of this economically active population was employed while the remaining was either unemployed or inactive (not actively seeking work and/or not available for work). The highest number of employed persons was in the 25 29 age group while the highest number of unemployed was in the $20-24$ age group with the proportion of unemployed males exceeding that of unemployed females. This shows that the level of unemployment is highest amongst the country's youthful males. The nature of the labour market remained broadly unchanged in 2012. The majority of the economically active population was employed with a salary in all the age groups except the age group 60 - 64 where most of the population was engaged in subsistence farming. Of those employed with a salary, 56.1 percent were females while 44.6 percent were males. Furthermore, the rates of unemployment were most predominant in the lowlands and foothills while lower in the country's mountainous districts [3] and 
[4].

Table 1 presents the number and percentage distribution of economically active population by employment status in Lesotho over the second quarter ${ }^{3}$ of 2014/15. Based on Table 1, it can be observed that 982, 656 people formed the economically active population with 74 percent of this employed whereas 26 percent was unemployed.

The unemployment rate in the second quarter of 2014/15 was an estimated 32.8 percent which translated into an economic dependency ratio of 1.41 during that time. 38.4 percent of the working population was engaged in elementary occupations which were highly labour intensive and used mostly hand-held tools. Table A1 shows that the greatest number of employed persons in the second quarter of 2014/15 was in the $25-29,30-34$ and 35 - 39 age groups. 32 percent of the 25 - 29 age group was employed as "clerical support workers" while the "armed forces occupations" accounted for the highest number of employed persons in the age group 35 - 39. In addition, the "Professionals" occupations recorded the highest percentage of employed in the 30 - 34 age group. Due to a less developed private sector, the public sector remains under great pressure to provide employment. This has resulted in large increases in the size of the public sector as well as recurrent public expenditure [5].

The main factors inhibiting returns to labour and jobs in Lesotho are lack of skills, high burden of disease especially HIV/AIDS and tuberculosis; poor investment climate and lack of key infrastructure [2]. In an attempt to address these challenges, one of the central goals of the Government of Lesotho's National Strategic Development Plan (NSDP) 2012/13-2016/17 is to pursue high, shared and employment creating economic growth. The Plan clearly states that the scourge of unemployment is not only one of the key challenges facing the country; but it is also a significant reason for a high prevalence of poverty and inequality. As a result, the NSDP targets the attainment of at least 50,000 sustainable private sector jobs by the end of the Plan period through the following seven strategies: 1) Mobilization of domestic and foreign savings and improving the investment climate; 2) Promoting economic diversification; 3) Improving quality and competitiveness of the labour force; 4) Facilitating technology transfer and partnerships for research; 5) Building minimum infrastructure platform, especially to link production centers and markets and to facilitate external trade and 6) Promoting global integration and trade; and 7) Development of the private sector.

Since the launch of the NSDP, some strides have been made by the Government of Lesotho towards the improvement of the country's investment climate as well as the development of key infrastructure. For instance, in 2014, Parliament approved the Industrial Licensing Act of 2014 whose purpose is to facilitate and promote industrial development and micro, small, and medium enterprises (MSMEs) through a new regulatory regime that is simple, short, and cost ${ }^{3}$ By the time of writing this research paper, the $4^{\text {th }}$ Quarter Continuous Multi-Purpose Survey of 2014/2015 had not been concluded. 
Table 1. Number and percentage distribution of economically active population $-2^{\text {nd }}$ quarter continuous multi-purpose survey 2014/2015.

\begin{tabular}{ccc}
\hline Labour Force & Frequency & Percentage \\
\hline Employed & 729,418 & 74 \\
Unemployed & 253,238 & 26 \\
Total & 982,656 & 100 \\
\hline
\end{tabular}

Source: [5].

effective. This initiative complements the amendment of the Trading Enterprises Regulations (1999) in December 2011 that has made it easier to obtain a trade license through the establishment of a One-Stop Business Facilitation Center (OBFC) and replacement of pre-inspection with post inspection for businesses with low health and environmental risks. Furthermore, there has been considerable improvement in the financial sector as it has become much easier for MSMEs to access credit due to reforms in the lending environment that reduced risk for banks. The land administration reform has greatly increased the availability of leasehold titles and streamlined the process of registering mortgage securities, leading to rapid growth in mortgage lending. In addition, The Financial Sector Development Strategy (FSDS) adopted by the government in 2013 has seen encouraging increases in the banking system's domestic loan-to-deposit ratio and a corresponding decrease in the portion of bank assets invested abroad, primarily in South Africa [2].

Last but not least, the Government of Lesotho in partnership the United Nations agencies launched the National Volunteer Corps Project (NVCP) and the Youth Employment Project (YEP) as part of its strategy to respond to high youth unemployment and poverty reduction. Furthermore, the Government of Lesotho in concert with commercial banks established of a M50 Million Partial Credit Guarantee Fund (PCGF) in May 2012 while another Partial Credit Guarantee Fund (PCGF) was launched by the Lesotho National Development Corporation (LNDC) in the same year. The main aim of these facilities was not only to encourage investors to start or expand MSMEs but also to support large businesses in the country. This was against the background that efforts to start or expand businesses particularly the MSMEs were fruitless due to lack of collateral. Therefore, these facilities encouraged the commercial banks to introduce easily accessible loan instruments for the business sector, especially the MSMEs, as they are able to recover a portion of their money in the event of a default.

\section{Review of the Literature}

\subsection{Theoretical Literature}

\section{1) Classical Theory of Unemployment}

Under the Classical theory of unemployment, the labour market is understood to be a single, static market that is characterised by perfect competition, spot transactions and institutions for double auction bidding. In this scenario, work- 
ers supply labour while employers demand it. The quantity of labour supplied can be interpreted by, for example, the number of workers working full days over a given period. On the other hand, the price of labour is the real wage per day. The theory assumes that every unit of labour services is the same and every worker in the labour market gets exactly the same wage. Moreover, under the classical theory, unemployment is a temporary phenomenon and the workings of the free market forces would ensure that the economy is restored to full employment given the flexible wages and perfect information assumptions [6] [7] and [8].

Figure 1 illustrates a case where the assumption of flexible wages does not hold and therefore the labour market does not clear. In Figure 1, the equilibrium wage is $\mathrm{W}^{\mathrm{E}}$ and the equilibrium quantity of labour supplied and demanded is $\mathrm{L}^{\mathrm{E}}$. The classical theory posits that if employers are expected to pay a minimum wage of say $\mathrm{W}^{*}$ (as depicted in Figure 1) this price will be well above the equilibrium wage. In this instance, the demand for labour at the minimum wage will be $\mathrm{L}^{\mathrm{D}}$ while the quantity of labour supplied will be $\mathrm{L}^{\mathrm{S}}$. Since the quantity of labour supplied outstrips the quantity of labour demanded at the minimum wage, the result is a labour surplus that translates into what is known as classical voluntary unemployment. Involuntary unemployment is only possible in instances where there are distortions $s^{4}$ in the functions of the labour market that prevent the market from clearing. In addition, the theory puts forward that there is no such thing as cyclical unemployment. People that are not working have either made decisions not to work or they are either part of frictional or structural unemployment [6] [7] and [8].

\section{2) Keynesian Theory of Unemployment}

The Keynesian school of thought explains unemployment as a cyclical and involuntary phenomenon where aggregate demand deficiencies over certain periods in the business cycle lead to a situation where there are not enough job opportunities to meet the number of people looking for work. Reference [7] explained that the level of aggregate employment is dependent on the level of aggregate demand in the economy as a whole. This relationship is illustrated in Figure 2.

Considering Figure 2, unemployment will prevail if there is a fall in aggregate demand that leads to a fall in firms' sales, which translates into a fall in firms' investment. This results in further declines in aggregate demand and even more unemployment [6] [7] and [8].

\subsection{Empirical Literature}

There are many studies that analyse the sources of unemployment in various countries around the world using Structural Vector autoregressive (SVAR)

${ }^{4}$ Over and above the minimum wage, other factors that could cause a distortion in the labour market could include labour-related regulations (such as safety regulations, mandated benefits, or restrictions on layoffs and firings) and labour union activities increase the cost of labour to businesses, causing them to turn towards labour-saving technologies and thus reducing job growth [7]. 


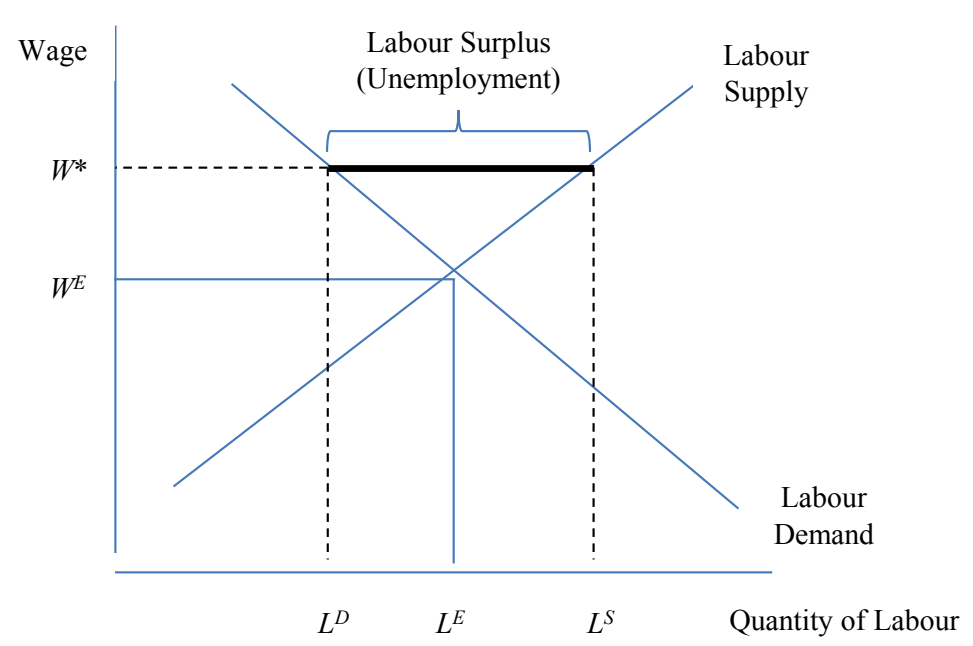

Figure 1. Unemployment under the classical theory.

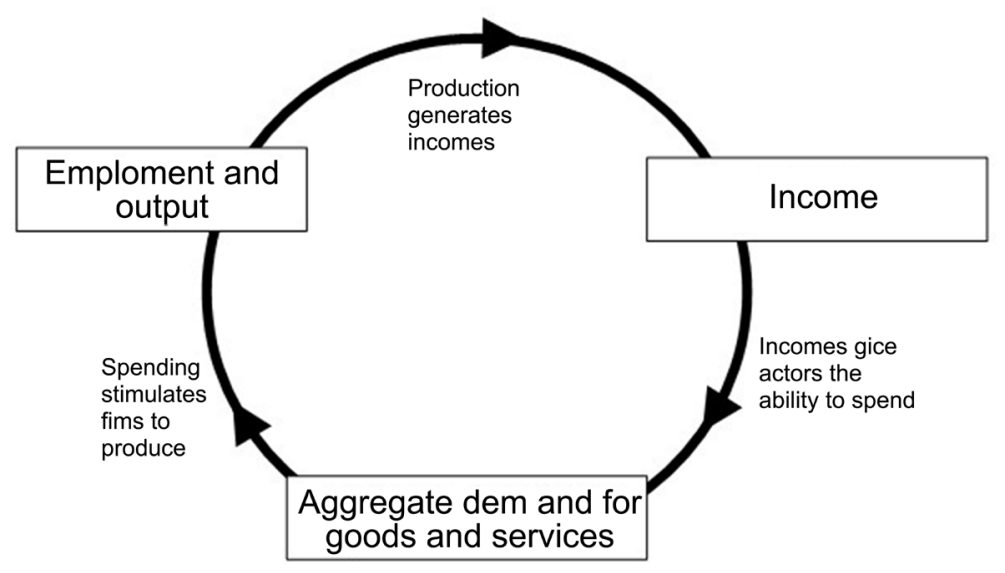

Figure 2. The keynesian model of employment determination.

framework. In the case of developed and emerging markets economies, [9] studied the sources of unemployment in Spain using a SVAR approach during the period 1971: Q1 to 1994: Q1. The empirical findings revealed that Spain's high unemployment was mainly driven by aggregate demand shocks, wage push, price push, productivity and labour supply shocks during the sample period. In a similar study, [10] analysed the dynamic effects of different macroeconomic shocks on unemployment in Germany during the time horizon 1969: Q1 to 1998: Q4 using SVAR approach. The empirical evidence from the impulse response functions (IRFs) and forecast error variance decomposition (FEVD) revealed that shocks to price, demand, and labour supply significantly affect unemployment in the short/medium term in Germany. Nevertheless, wage and technology shocks seem to play a minor role in explaining unemployment dynamics in that country during that period. In another study [1], also examined the patterns of unemployment dynamics in Germany by means of SVAR framework but their sample period covered the period 1981-2007. The results provided evidence that the job finding rate played a larger role in explaining 
unemployment after a technology shock and a monetary policy shock on the one hand. On the other hand, the separation rate appears as the dominant margin following a fiscal policy shock.

In a different study [11], disentangled the main sources of the high unemployment rate in Italy over the sample period 1956Q1-1998Q3 using the SVAR approach. The empirical findings revealed that the high Italian unemployment rate was attributed to non-demand factors such as productivity and labour supply shocks, whose effect was temporary on the one hand. On the other hand, it was permanently affected by shocks to wage bargaining schedule, which explained a gradual rise of approximately 2.5 percentage points over the last 15 to 20 years. A few years later [12], employed a similar approach (SVAR) to assess the dynamic responses of labour productivity, real wage, and unemployment rate to technology, aggregate demand, and mark-up shocks in Italy during the period 1960-1999. The results revealed that both mark up and aggregate demand shocks permanently reduce the unemployment rate while shocks to technology do not significantly affect the unemployment rate in the long-run. Furthermore, demand and supply shocks were found to permanently affect the unemployment rate in Italy.

In the context of Austria [13], employed the SVAR framework to study the effect of shocks to productivity, demand, wages and labour supply during the period 1964: Q1-1999: Q2, assuming full hysteresis in the Austrian labour market. The analysis of the impulse responses showed that a productivity shock reduces unemployment rate perhaps partly due to a reduced labour supply, a demand shock reduces unemployment rate for the first two years and this effect decreases in the following two to three years. In addition, a labour supply shock permanently affect unemployment rate while it responds less significantly to a wage push. The analysis of the forecast variance decomposition revealed that unemployment was driven mostly by labour supply shocks with its effect diminishing over time, followed by shocks to demand and productivity with wage shock having no impact on unemployment due to hysteresis.

Using the SVAR model with long-term restrictions proposed by [11] [14] analysed the factors that predetermined unemployment rate in Lithuania during the period 2001Q1-2014Q2. The empirical findings revealed that changes in unemployment during the period of 2002 to 2014 were largely influenced by cyclical shocks (of productivity as well as labour supply and demand) with just short-term effects ${ }^{5}$ on the one hand. On the other hand, it is predetermined by structural shocks (the wage-push shock) with long-term effects. Similarly [15], employed autoregressive distributed lag (ARDL) cointegration approach in conjunction with the SVAR framework to investigate the potential impact of unemployment rates on the Romanian shadow economy for the period 2000Q12013Q4. This was done with a view to examine the extent to which countries win ${ }^{5}$ Among these shocks, productivity shocks explain the largest share of the unemployment dynamics during the economic cycle. According to the authors, this finding is very close to the business cycle theory which explains the cyclical nature of the economy by changes in productivity. 
or lose by not taking the effect of the informal economy on macroeconomic indicators into account. ARDL approach analysis revealed absence of cointegration between unemployment rates and the Romanian shadow economy while the IRFs derived from the SVAR framework showed that a rise in the recorded unemployment rate will lead to an increase in the size of the shadow economy in the short run while an increase in the International Labour Organisation (ILO) unemployment rate highlighted a decrease in the size of the shadow economy. Other studies that examine the sources of unemployment in developed and emerging markets economies include but are not limited to [16] for the case of Sweden, [17] for France and United States (US) [18], as well as [19] for European countries.

In the case of developing countries especially in Africa, studies of this nature have also been done though the coverage remains low compared to developed and emerging markets economies. This is despite the importance of the issue of unemployment and/or employment for policy formulation in developed and developing countries alike. Even where such studies have been done they have not used the SVAR approach. For instance [20], analysed the determinants of unemployment in Swaziland through use of Engle-Granger (E-G) two-step econometric procedure and Granger causality tests during the period 1992-2012. The empirical results revealed that unemployment in Swaziland is determined by gross domestic product (GDP), inflation and government spending. In a similar study in Namibia, [21] examined the determinants of unemployment during the period 1970-2007, using E-G procedure. The results indicated that unemployment in Namibia is affected by actual output, inflation, investment and aggregate demand. There are also several studies which analyse the sources of unemployment in South Africa using other techniques including cointegration and error correction models (see [22] [23] [24] among others), However, in line with arguments by [25], these techniques impose possibly incorrect restrictions in the model, and this weakness leads to the preference of VARs, which treat all variables as endogenous.

In a different study [26], analysed the effects of monetary policy on unemployment in Namibia using the SVAR model for the period 1980 to 2013. This study developed the SVAR model using three modular experiments. The first stage involved specification of the basic model using productivity, real wage, unemployment and the interest rate. The analysis of the IRFs and FEVD revealed that the fluctuations in unemployment are mainly explained by own shocks and productivity shocks both in the short run and long run on the one hand. On the other hand, monetary policy and real wages do not significantly explain unemployment fluctuations in both the short run and long run. In the second stage, the study used the demand, labour market and exchange rate channels to establish if some additional information from these channels can be derived, which explain the monetary transmission process in Namibia. The findings revealed that the demand and exchange rate channel variables could be incorporated in the small macro-econometric model for Namibia. The analysis 
of the IRFs and FEVD confirmed the results from the basic model that unemployment in Namibia is only affected slightly in the short run by the various shocks; however, those responses die out in the long-run. In another study [27], further studied the sources of unemployment in Namibia for the period 1980 to 2013 using the same SVAR methodology. The empirical results revealed that persistently high unemployment is not only attributed to a combination of different shocks hitting the Namibian economy but also due to hysteresis. In particular, the analysis of the IRFs and FEVD indicate that high unemployment in Namibia is attributed to labour supply, aggregate demand, and real wages shocks. In addition, in the long term the price shocks affect unemployment while and productivity shocks explain only a small fraction of unemployment both in the short and long term in that country.

In light of this review of the literature, it is obvious that the studies that examine the sources of unemployment using SVAR methodology in developing countries, especially in landlocked countries that are economically characterised by poverty and close relationship with a more economically developed country, whose currencies are pegged to that of a dominant trading partner such as Lesotho ${ }^{6}$, remain scant. Therefore, the current study analyses the sources of unemployment in Lesotho that was ranked a middle income country in 2016, despite the existence of extreme poverty, high income inequality and prevalence of HIV/AIDs as well as persistently high unemployment rate. This combination of traits arguably has the potential to lead to some interesting revelation with respect to the sources of unemployment and may have interesting economic policy implications regarding what could be done to reduce high level of unemployment in Lesotho.

\section{Analytical Framework}

\subsection{Data Description and Sources}

This research paper makes use of annual time series data from 1980 to $2014^{7}$. Table A2 provides a detailed description of the variables used in the study and data sources. The variables used in the VAR model are productivity $(P R D)$, employment $(E M P)$, real wage $(R W G)$, consumer price index $(I N F)$ and unemployment (UEM). It is important to note that where data gaps were identified, interpolation and extrapolation methods were used to generate the missing data. Data for UEM was missing for the period 1980 to 1989 but was available from 1990 to 2014. Therefore, the study used backward extrapolation as espoused by [28] [29] [30] [31] [32] and [33] to generate $U E M$ data for the period 1980 to 1989. In order to calculate $R W G$, the study made use of a method employed by [34] as well as [27]. All the variables in the model are expressed in natural logs except INF which is expressed as percentages.

${ }^{6} \mathrm{~A}$ country that has been considered in this review of empirical literature and that has the same characteristics as Lesotho is Swaziland.

${ }^{7}$ The sample time frame has been selected on the basis of data availability. 


\subsection{Model Specification}

In order to obtain the dynamic interactions among LPRD, LEMP, LRWG, INF and $L U E M$ in Lesotho, the study used a structural VAR (SVAR) model whose data generation process (DGP) is underpinned by a reduced form VAR. The VAR has superiority over other econometric methods such as simultaneous equations due to its capability to quantify the average contribution of a given structural shock to the variability of the data over time through what are known as forecast error variance decompositions (FEVDs) (See, [35] [36] [37] [38] [39] as well as [40]). In addition, the VAR model can be used to develop historical decompositions that measure the cumulative contribution of each structural shock in the evolution of each variable over time [41].

The reduced form VAR is presented as:

$$
Z_{t}=G_{0}+G_{1} Z_{t-1}+G_{2} Z_{t-2}+\ldots+G_{s} Z_{t-s}+\varepsilon_{t}
$$

where $Z_{t}$ is a $(5 \times 1)$ vector of endogenous variables $\left(L P R D_{t}, L E M P_{t}, L R W G_{p}\right.$ $I N F_{t}$ and $\left.L U E M_{t}\right)$ observed at time $t . G_{0}$ is a $(5 \times 1)$ vector of constants, $G_{1,2, \ldots, s}$ is a $(5 \times 5)$ matrix of coefficient estimates, $\varepsilon$ is a $(5 \times 1)$ vector of serially uncorrelated system innovations and $s$ is the optimal lag length of each variable. When unpacked, the VAR model in Equation 1 is a system of five equations. Therefore, equation 1 can be estimated using the ordinary least squares (OLS) method after the choice of optimal lag length (VAR order) has been selected. Reference [37] indicated that the VAR order is chosen by means of the smallest information criterion such as Akaike information criteria (AIC), Schwarz information criterion (SIC) and Hannan-Quinn information criterion (HQ). In this regard, the study employs these three information criteria for the choice of the optimal lag length. Once the VAR model is estimated, the system will be tested for stability through the autoregressive (AR) roots table. The VAR model is regarded to be stable if the modulus of each root lies within the unit circle.

\subsection{Unit Root Tests}

Prior to undertaking any empirical analysis of the data, the paper determines the order of integration of the variables. For this purpose, the study utilised the Augmented Dickey and Fuller (ADF) by [42] and [43] as well as the Phillips-Perron (pp) tests by [44] to check the order of integration of the variables. The latter test is used in addition to the former test because it is non-parametric in nature and, therefore, it caters for serial correlation, endogeneity of the regressors and allows for the possibility of heteroskedasticity in the errors [45].

\subsection{Model Checking}

It is essential to establish the integrity of Equation (1) in the DGP before the SVAR can be estimated. To this end, the study focuses on tests for residual autocorrelation $^{8}$, heteroskedasticity and structural stability. Normality tests were ${ }^{8}$ To test for autocorrelation in the residuals, the study uses the Breusch-Godfrey LM test. According to [37], this is the most suitable test for checking autocorrelation in VARs. 
not conducted since normality is not a necessary condition for the validity of statistical procedures related to VAR models [37].

\subsection{SVAR Identification}

Once all the necessary model checking has been done and it has been confirmed that equation 1 passes the relevant residual diagnostics and structural stability tests, the next step is to specify and estimate the SVAR model. From the SVAR model, structural shocks can be isolated. This allows for the generation of IRFs, FEVDs and the historical decomposition [40]. The structural representation of the VAR model is represented in Equation (2)

$$
A X_{t}=\beta_{0}+\beta_{1} X_{t-1}+\beta_{2} X_{t-2}+\ldots+\beta_{s} X_{t-s}+v_{t}
$$

where; $A$ is a $(5 \times 5)$ matrix of instantaneous relations among the endogenous variables where the diagonal elements are normalized to equal one but the off diagonal elements may be arbitrary. $X_{\mathrm{t}}$ is a $(5 \times 1)$ vector of endogenous variables $\left(L P R D_{p} L E M P_{t} L R W G_{t} I N F_{p}\right.$ and $\left.L U E M_{t}\right)$ observed at time $t . \beta_{0}$ is a vector of constants, $\beta_{1,2, \ldots, s}$ is a $(5 \times 5)$ matrix of coefficient estimates, $v$ is a $(5 \times 1)$ vector of serially uncorrelated structural errors and $s$ is the optimal lag length of each variable

The SVAR model cannot be estimated with OLS because of the contemporaneous relations between the endogenous variables in matrix $A$ that are correlated with the structural errors. Therefore, to estimate the SVAR model and develop IRFs and FEVDs, Equation (2) needs to be identified. This is done by imposing restrictions on elements of matrix $A$ in Equation (2). Reference [40] explained that imposing restrictions to matrix $A$ in Equation (2) also means imposing restrictions on the inverse of matrix $A$, that is; $A^{-1}$. Multiplying the right and left hand sides of the SVAR model by $A^{-1}$ results in the reduced form VAR in Equation 1, represented below as Equation 3 such that

$$
Z_{t}=A^{-1} A X_{t}
$$

The relationship between the forecast errors and structural shocks is represented by Equation (4)

$$
\varepsilon_{t}=A^{-1} v_{t}
$$

In order to obtain the structural innovations in equation (4), the study employed a strictly recursive Cholesky decomposition technique where

$$
\frac{\left(n^{2}-n\right)}{2}
$$

zero (exclusion) restrictions ${ }^{9}$ are imposed. The Cholesky decomposition used in this study has the following ordering: $L P R D_{t} L E M P_{t} L R W G_{t} I N F_{t}$ and $L U E M_{t}$. This ordering was used by [27]. With this ordering, the study assumes the following:

1) Productivity $(L P R D)$ is not contemporaneously affected by any of the ${ }^{9}$ Where $n$ is the number of endogenous variables in the model. 
shocks. It is only affected by own shocks while all other shocks will affect it with a lag.

2) Employment (LEMP) is contemporaneously affected by productivity shocks and own shocks while all other shocks will affect it with a lag.

3) Real wage $(L R W G)$ responds contemporaneously to productivity shocks, employment shocks and own shocks, while all other shocks will affect it with a lag.

4) Inflation (INF) responds contemporaneously to own shocks and all other shocks except the unemployment shock

5) Unemployment (LUEM) contemporaneously responds to own shocks and shocks from all the variables in the model.

There are five endogenous variables. Therefore, Equation (2) is just-identified when ten zero exclusion restrictions are imposed on matrix A in Equation (2).

\section{Analysis of Empirical Results}

\subsection{Results of the Unit Root Tests}

As a normal practice in time series analysis, the paper performs the standard Augmented Dickey-Fuller (ADF) and Phillips-Perron (PP) unit root tests to check the order of integration of the variables prior to estimating the reduced form VAR model in Equation (1). Table 2 presents the results of the ADF and PP unit root tests both in levels and first differences of the variables. The results of these tests provide empirical evidence that all the variables, namely; LEMP, $L P R D, L R W G, L U E M$ are integrated of order one, that is, $[I(1)]$ except the $I N F$, which appears to be integrated of order zero, that is, $[I(0)]$.

Given the results of the unit root tests above, the issue would now be on the choice of the appropriate econometric strategy (analytical technique), which allows for the empirical analysis of the sources of unemployment in Lesotho in the presence of a mixture of $[I(0)]$ or $[I(1)]$ variables. There are various econometric tools which could be employed under this circumstance. For instance, one would estimate a cointegration relationship among these variables through use of analytical tools such as autoregressive distributed lag (ARDL) bounds testing procedure or estimate a VAR model in which the INF variable is treated as an exogenous variable, etc.

Table 2. ADF and PP unit root test results.

\begin{tabular}{ccccc}
\hline Variables & \multicolumn{2}{c}{ ADF Test } & \multicolumn{2}{c}{ Phillips Perron(PP) Test } \\
\hline & Level & First Differences & Level & First Differences \\
\hline LEMP & $-1.5157(0.5137)$ & $-6.0057^{\star}(0.0000)$ & $-1.2776(0.6285)$ & $-7.5751^{\star}(0.0000)$ \\
LPRD & $-1.0573(0.7210)$ & $-6.3937^{\star}(0.0000)$ & $-0.9628(0.7552)$ & $-12.2156^{\star}(0.0000)$ \\
LRWG & $-0.8078(0.8041)$ & $-6.1214^{*}(0.0000)$ & $-0.9167(0.7706)$ & $-10.0063^{\star}(0.0000)$ \\
LUEM & $-2.1048(0.2441)$ & $-5.5953^{*}(0.0000)$ & $-0.1718(0.2197)$ & $-5.7171^{\star}(0.0000)$ \\
INF & $-5.9362^{*}(0.0000)$ & & $-5.9474^{\star}(0.0000)$ & \\
\hline
\end{tabular}


However, the current study follows existing studies in the literature (see [25] [46] and [47] [48] and [49]), which typically estimates VAR models in levels, through the SVAR framework, despite the possibility of non-stationarity among the variables. This is because the study intends to trace out the underlying interrelationship among the variables rather than determining the development of parameter estimates. Therefore, it is unnecessary to transform models to stationary forms by difference or cointegration operators even when it appears likely that data are cointegrated because the statistics of interest frequently have distributions that are not affected by non-stationarity, and this makes it possible to test the hypothesis even without initially converting series to stationarity [25]. In addition, differencing of the variables to achieve stationary may lead to loss important information concerning the co-movements of the variables [50] and [51]. Besides that, levels specification leads to consistent estimates regardless of whether cointegration exists or not, whereas a differences specification yields inconsistent estimates in the event that some of the variables are cointegrated (see [52]). Other studies that support this approach are [53]-[60].

\subsection{Optimal Lag-order Selection and Residual Diagnostic Tests}

According to Khan and Ahmed [48] and [49], the choice of the sufficient number of lags is very important to remove serial correlation and make the errors stationary in a VAR model. In this regard, the choice of the optimal lag length for the level VAR model was determined by considering the Akaike information criteria (AIC), Schwarz information criterion (SIC) and Hannan-Quinn information criterion (HQ). Table A3 presents the results of the selection of the optimal lag length by AIC, SC and HQ. According to the results, all the information criteria propose lag 1 as optimal for the VAR model. Reference [61] states that the estimation of VAR in levels is more appropriate when the error terms in each VAR equation are stationary and serially uncorrelated. Therefore, in an effort to confirm the lag order choice by these information criteria, the study further performed an autocorrelation LM test to eliminate the possibility of serial correlation at that lag. Table A4 and Table A5 present the results of the VAR autocorrelation LM test and VAR Residual Serial Correlation LM tests, respectively, while the results of the VAR stability test are presented in Table 3. The results indicate that the errors in the estimated VAR model are not serially correlated and are homoskedastic under lag 1 . In addition, under the same lag order, no root lies outside the unit circle. Therefore, Equation 1 was estimated using ordinary least squares (OLS) with a lag length of 1 .

\subsection{Impulse Response Functions (IRF) Analysis}

As mentioned earlier, the main objective of this paper is to track out responses of unemployment to shocks in productivity, employment, and real wage and inflation by means of impulse response analysis. For this purpose, we have estimated SVAR model in levels and derived the impulse response functions (IRFs). 
Table 3. VAR Stability Test.

\begin{tabular}{cc}
\hline \multicolumn{2}{c}{ Roots of Characteristic Polynomial } \\
\hline Endogenous variables: $L P R D$ LEMP LRWG INF LUEM \\
\hline Root & Modulus \\
\hline 0.998654 & 0.9986539041076444 \\
$0.704411-0.224126 \mathrm{i}$ & 0.7392071701120861 \\
$0.704411+0.224126 \mathrm{i}$ & 0.7392071701120861 \\
$-0.100606-0.219044 \mathrm{i}$ & 0.2410433043411363 \\
$-0.100606+0.219044 \mathrm{i}$ & 0.2410433043411363 \\
\hline No root lies outside the unit circle. & \\
VAR satisfies the stability condition
\end{tabular}

Figure 3 contains the IRFs for the unemployment to one standard deviation shock in productivity, employment, real wage inflation. The IRFs (represented by solid lines in the Figure 3 ) are interpreted as the percentage change in one variable after a one percent increase in another variable. However, different authors in the literature interpret them differently. One strand of the literature, similar to [62], defines "statistically significant" impulse responses as those estimates for which the narrow error band does not include zero. On the other hand, the other part of the literature (such as [63]) defines them as statistically significant even if the narrow bands include zero as long as the solid lines do not touch zero. This study adopts the -latter interpretation of the IRFs.

The impulse response of unemployment to the positive productivity shock is positive and immediate registering approximately 0.04 percent and peaks in the $2^{\text {nd }}$ year at 0.063 percent before decreasing and becoming statistically insignificant at the beginning of the $4^{\text {th }}$ year. Thereafter, unemployment's response is negative and stays negative for the remaining period until the tenth year. This finding implies that productivity initially increases unemployment up to 4 years in Lesotho. Thereafter, the impact becomes negative. This empirical finding is inconsistent with that of [27], who found that positive productivity shocks decreased unemployment significantly in the first five years but is consistent with that of [9] who attributed this development to the so called "technological bias" that explains unemployment as a temporary phenomenon.

It appears that employment immediately and significantly lowers unemployment by 0.12 percent with the impact remaining negative up to the $3^{\text {rd }}$ year. This empirical finding is consistent with the standard economic theory. However, after the $3^{\text {rd }}$ year, the response of unemployment to a one percent positive shock in employment becomes positive and fairly stable until the $10^{\text {th }}$ year. This empirical finding is consistent with that of [27] but it is at variance with the result of [63], who established that unemployment permanently decreases after an aggregate demand shock. The short lived negative impact of the employment shock on unemployment could mean that the nature of employment in the country is of a 
Response to Cholesky One S.D. (d.f. adjusted) Innovations \pm 2 S.E.

Response of LUEM to LPRD

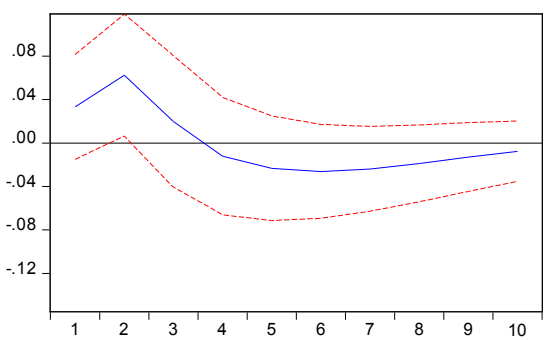

Response of LUEM to LRWG

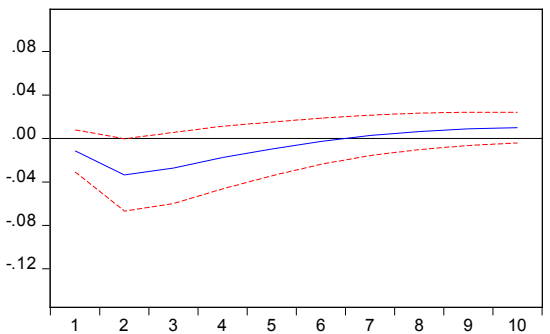

Response of LUEM to LUEM

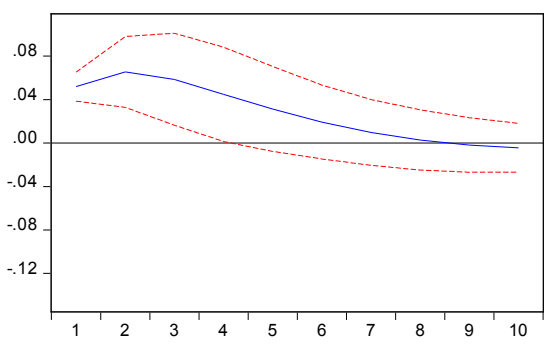

Response of LUEM to LEMP

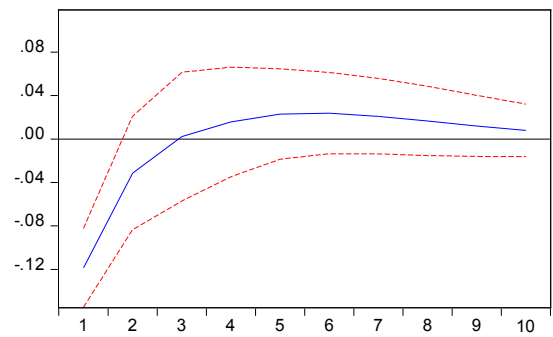

Response of LUEM to INF

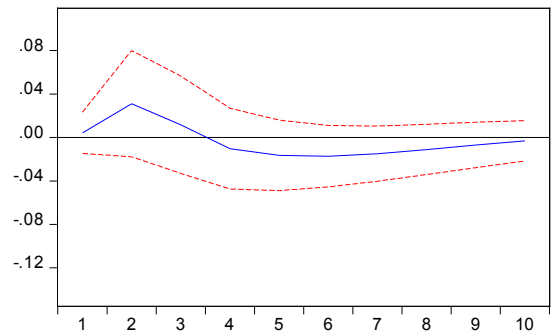

Figure 3. The IRFs of the responses of unemployment to shocks to productivity, employment, real wages, inflation and unemployment's own shocks.

short term nature.

With respect to real wage, the IRFs indicate that a positive shock to real wages immediately and significantly lowers unemployment with the highest dip of 0.03 percent in the $2^{\text {nd }}$ year. Thereafter the impact remains negative until the $7^{\text {th }}$ year after which it becomes positive until the $10^{\text {th }}$ year. The impact of a wage shock on unemployment from the $1^{\text {st }}$ year to the $7^{\text {th }}$ year contradicts economic theory, where an increase in real wages lowers unemployment. A possible explanation could be that firms' initial gain in competitiveness after an increase in labour productivity enables them to set higher prices that temporarily offset any increase in wages. This finding is similar to that of [64] who established that in the first few years, a positive real wage shock decreases unemployment before leading to an increase in unemployment. The impact of a wage shock from the $7^{\text {th }}$ year to the end of the period is consistent with economic theory in that a positive shock to real wages leads to an increase in unemployment. The assumption is thatit becomes costly for the employers to hire new employees or even maintain the existing number of employees. 
Regarding inflation, it appears that a positive shock to inflation immediately and significantly increases unemployment for the first 3 years, peaking in year 2 at 0.03 percent, after which the impact becomes negative. This empirical evidence is in line with the economic theory and may be on account of increased cost of labour and production in the first 3 years. Therefore, price inflation shocks are a critical factor for high unemployment in Lesotho within a short time horizon. These findings are in line with [63], [12] and [27] and imply that a positive shock in inflation is expected to translate into higher costs for the firms, which will usually respond by laying off workers and therefore increases unemployment. The decline in unemployment from the $4^{\text {th }}$ year onwards due to a positive inflation shock could mean an internalisation of the costs of inflation by firms. Finally, it appears that a positive shock to unemployment immediately and positively increases unemployment for 8 years. This finding is consistent with that obtained by [27].

In summary, the preceding analysis shows that shocks to the level of employment, productivity, real wages, inflation and unemployment itself are critical factors explaining unemployment dynamics in Lesotho.

\subsection{Forecast Error Variance Decomposition (FEVD) Analysis}

According to [37] [40] [65] along with [48] and [49], the FEVD analysis not only provides a tool of analysis used to identify relative importance of each dependent variable in explaining the variations in the explanatory variables but also assists in terms of providing an insight into the transmission channels through which policy-specific shocks spill over. Table 4 presents the results of FEVDs of unemployment over a 10-year horizon for positive shocks in productivity, employment, real wage and inflation. The empirical results in Table 4 generally reveal that in the $1^{\text {st }}$ year up to the $10^{\text {th }}$ year, the total variation in unemployment in Lesotho is mainly explained by shocks to the level of employment, followed by own shocks,

Table 4. Forecast error variance decomposition of unemployment.

\begin{tabular}{ccccccc}
\hline Period & S.E. & LPRD & LEMP & LRWG & INF & LUEM \\
\hline 1 & 0.288348 & 6.131027 & 78.07416 & 0.729601 & 0.097615 & 14.96760 \\
2 & 0.444564 & 17.14009 & 51.39727 & 4.308218 & 3.340607 & 23.81381 \\
3 & 0.452775 & 15.92130 & 44.28794 & 5.898842 & 3.278075 & 30.61384 \\
4 & 0.460350 & 15.10720 & 41.57523 & 6.287392 & 3.315325 & 33.71485 \\
5 & 0.468976 & 15.55946 & 40.36243 & 6.138150 & 3.806087 & 34.13387 \\
6 & 0.477925 & 16.49755 & 39.84452 & 5.868429 & 4.353753 & 33.43576 \\
7 & 0.487382 & 17.32106 & 39.62462 & 5.701674 & 4.746214 & 32.60644 \\
8 & 0.497214 & 17.81720 & 39.52686 & 5.692193 & 4.943168 & 32.02057 \\
9 & 0.507265 & 18.02337 & 39.45781 & 5.811277 & 5.002862 & 31.70469 \\
10 & 0.517400 & 18.05142 & 39.37663 & 6.007297 & 4.997163 & 31.56748 \\
\hline
\end{tabular}

Cholesky Ordering: LPRD LEMP LRWG INF LUEM. 
shocks to productivity, shocks to real wages and last but not least the shocks to price inflation. For instance, in the $1^{\text {st }}$ year, approximately 78 percent of total variation in unemployment is explained by shocks to the level of employment while own shocks account for approximately 15 percent of the variation in unemployment. Shocks to productivity, real wages and inflation collectively explain only the small fraction of the variation in unemployment. Specifically, the shocks to these variables explain approximately 6.13 percent of the variation in unemployment rate in Lesotho in the $1^{\text {st }}$ year. In the $5^{\text {th }}$ year approximately 40 percent of variation in unemployment is explained by shocks to the level of employment; while approximately 30 percent is explained by own shocks and about 16 percent explained by shocks to the level of productivity in the economy. Real wages and inflation collectively account for only about 9.94 percent of the total variation in unemployment.

In the $10^{\text {th }}$ year, 39 percent of variation in unemployment is explained by shocks to the level of employment whereas approximately 31 percent is explained by own shocks. In addition, shocks to productivity explain about 18 percent of the variation in unemployment while shocks to real wages and inflation collectively explain only about 11 percent of the variation in unemployment during the same time horizon. In this regard, the importance of the shocks emanating from productivity, real wages and inflation in explaining variation in unemployment grows over time while that of shocks to employment and own shocks decline over time.

In summary, the results reported in Table 4 largely confirm the findings from the IRFs presented in Figure 3. In other words, the variation in unemployment in Lesotho is largely results from shocks to employment level, own shocks, productivity shocks and shocks to both real wages and inflation.

\subsection{Historical Decomposition of Unemployment}

Apart from employing IRFs and FEVD, the paper further uses historical decompositions to estimate the individual contributions of each structural shock to the movements in unemployment in Lesotho over the sample period. According to [66], the historical decompositions of each variable into the estimated structural shocks are calculated as:

$$
Y_{t}=A^{t} Y_{0}+\sum_{k=1}^{t} A^{t-k} e_{k}
$$

Equation (5) states that the model variables at each point in time $\left(Y_{t}\right)$ are represented as the function of initial values $\left(Y_{0}\right)$ plus all the structural shocks of the model. Figure 4 shows the historical decomposition of the shocks to unemployment over the sample period 1980-2014.

Figure 4 depicts that between 1980 and 1995 unemployment was positive. During this time, shocks to productivity, employment, inflation, as well as own shocks exerted downward pressure on the level of unemployment in Lesotho where as shocks to real wage make a positive contribution to unemployment 


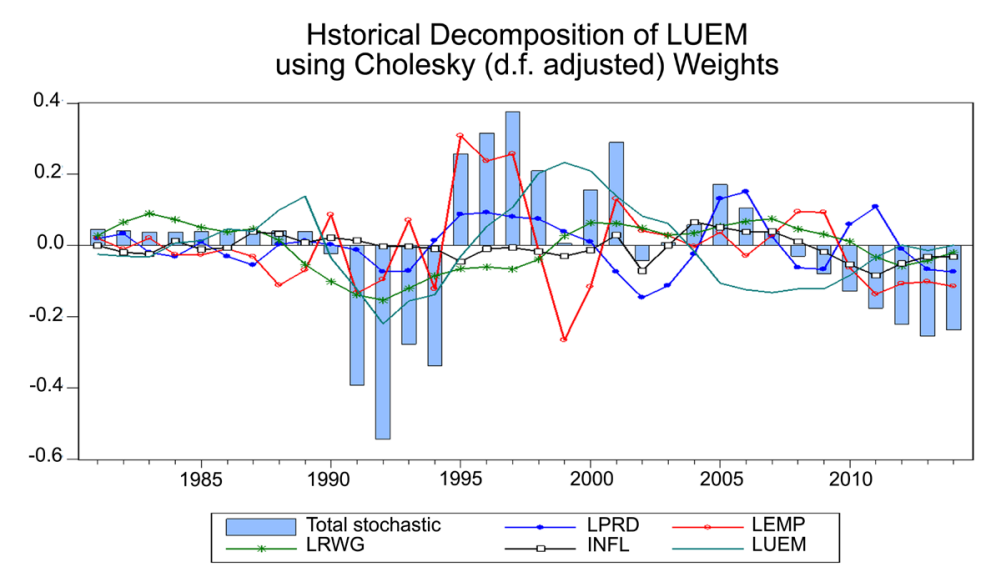

Figure 4. Historical decomposition of the shocks to unemployment.

from 1980 to 1988. From 1990 to 1994 unemployment was in decline. This was mostly affected by productivity, real wage and own shocks that applied downward pressure on the level of unemployment while employment had mixed impacts during this time.

During the period 2000 to 2010 , the shocks to real wages, inflation, productivity and employment generally contribute positively to explain the dynamics of unemployment in Lesotho. On the other hand, the own shocks make a negative contribution to level of unemployment during that time horizon. From 2010 to 2014, the shocks to real wages, inflation, and employment as well as own shocks play a dampening role in unemployment dynamics. Productivity shocks positively contribute to unemployment between 2010 and 2012 in Lesotho, and thereafter put downward pressure on unemployment dynamics until the end of the sample period.

To sum up, employment shocks, own shocks and productivity shocks are the most important drivers behind the dynamics of unemployment in Lesotho while real wage and inflation only moderately contribute in explaining such dynamics. This empirical evidence is exactly congruent to the finding derived from the IRFs and FEVD.

\subsection{Robustness Checks}

Having estimated the IRFs, FEVDs and historical decompositions for the sources of unemployment based on SVAR in Lesotho, it is crucial to confirm that the robustness of the obtained results to ensure their reliability for policy analysis. As an initial robustness check, the errors in the reduced form VAR, Equation (1), were tested for the presence serial correlation and heteroskedasticity at the optimal lag order of 1 (chosen by the information criteria, see Table A3). The results of these tests, presented in Appendices 4 and 5, provided empirical evidence that the errors of the reduced form VAR model were serially uncorrelated and homoskedastic. As mentioned earlier, the estimated VAR model was also tested to ensure that it satisfied the stability condition. This stability tests requires that all roots of the characteristic polynomial should be inside the unit 
circle [38]. The VAR model stability test presented in Table 3 indeed shows that the estimated reduced form VAR satisfied the stability condition.

Last but not least, the robustness test similar to that used by Bank (2011), which involves the analysis of different specifications of the reduced form VAR by changing the ordering of the endogenous variables using Cholesky decomposition was also conducted. Reference [67] cautioned that under the Cholesky decomposition, the ordering of variables before and after the variable of interest (in this case, unemployment) has no consequence on the variables of interest. This means that if the ordering is not changed for the unemployment variable but is changed for all other variables, then the same result as the initial ordering will be obtained. For this purpose, the unemployment variable was ordered second. The results of the IRFs and FEVDs, as outlined in Table A6 and Figure A1, respectively show that the results are broadly unchanged.

\section{Conclusions and Recommendations}

In the past decade, Lesotho's growth rate averaged about 3.8 percent with growth primarily driven by substantially expanding public activities especially government spending. Despite this, unemployment, poverty and income inequality and other social ills remained stubbornly pervasive in the face of non-inclusive growth in the economy. Labour market deficiencies, undiversified markets and small private sector, among others, are to blame for this high unemployment in the economy. With few job opportunities at home and higher wages in the neighbouring South Africa, a sizeable proportion of Lesotho's labour force used to seek employment in South Africa. However, South Africa's policy shift towards the use of local labour significantly reduced the demand for labour from Lesotho. This situation not only worsened the already obstinately high unemployment but also increased income inequality and poverty and other social ills in the country.

This paper employed SVAR framework to investigate the sources of the high unemployment in Lesotho during the period 1980 to 2014 with a view of contributing to the general body of knowledge on causes of unemployment in developing countries that are landlocked and of which the national currency is pegged to that of a highly dominant trading partner. The empirical analysis derived from the IRFs reveal that positive productivity shocks increase unemployment for up to 4 years but thereafter decreases it. This could perhaps be attributed to, inter alia, "technological bias" which explains unemployment as a temporary phenomenon. In addition, a positive employmentshock has a short-lived negative impact on unemployment and this result could be due to the short-term nature of employment in the country. Furthermore, a positive real wages shock was found to decrease unemployment for a period of 7 years before increasing it. Lastly, the empirical analysis also shows that a positive shock to inflation instantaneously and significantly increases unemployment for the first 3 years after which the impact becomes negative with unemployment probably decreasing as 
firms internalise the inflation costs. On the same token, a positive shock to unemployment itself immediately and positively increases unemployment for a period of 8 years and decreases it thereafter. These empirical findings were also corroborated by results of the FEVD and historical decomposition, both of which reveal that the variation in unemployment largely emanates from shocks to employment, unemployment itself, productivity, real wages and inflation. However, the importance of positive shocks to employment and unemployment itself in explaining the variation in unemployment decline over time while of the impact of positive shocks to productivity, real wages and inflation grow over time.

In light of these empirical findings, the study recommends that the government should invest in activities that are geared towards the promotion of the private sector and economic diversification in order to increase the level of output while at the same time creating various employment opportunities. This will also help to relieve pressure on the public sector and enhance labour market competitiveness and flexibility, reduce labour costs and encourage the creation of more employment opportunities. In addition, the government's fiscal policy should ensure that expenditure is channelled towards investment in human and physical capital development. This will not only aid in closing the existing skills gap but will also result in positive spillovers that will increase economic growth, translate in to job creation and a smoothing of the business cycle.

\section{References}

[1] Nordmeier, D. and Weber, E. (2013) Patterns of Unemployment Dynamics in Germany. IAB-Discussion Paper, No. 2/2013.

[2] World Bank (2015) Lesotho-Systemic Country Diagnostic. http://documents.worldbank.org/curated/en/371421468188678379/Lesotho-System atic-country-diagnostic

[3] Bureau of Statistics (BoS) (2011) 2008 Lesotho Integrated Labour Force Survey. http://www.bos.gov.ls/New\%20Folder/Copy\%20of\%20Demography/2008_ILFS_rep ort.pdf

[4] Bureau of Statistics (BoS) (2014) 3rd Quarter Continuous Multi-Purpose House Hold Survey 2011/2012. http://catalog.ihsn.org/index.php/catalog/4917

[5] Bureau of Statistics (BoS) (2017) 2nd Quarter Continuous Multi-Purpose House Hold Survey 2014/15.

[6] Holte, F.C. (1988) Four Papers on the Theory of Unemployment. Statistisk Sentralbyrå.

[7] Goodwin, N.R., Nelson, J.A., Ackerman, F. and Weisskopf, T. (2006) Theories of Unemployment.

https://www.saylor.org/site/wp-content/uploads/2010/11/Theories-of-Unemployme $\underline{\text { nt.pdf }}$

[8] Dagume, M.A. and Gyekye, A. (2016) Determinants of Youth Unemployment in South Africa: Evidence from the Vhembe District of Limpopo Province.

[9] Balmaseda, M., Dolado, J.J. and Lopez-Salido, J.D. (2000) The Dynamic Effects of Shocks to Labour Markets: Evidence from OECD Countries. Oxford Economic Pa- 
pers, 52, 3-23. https://doi.org/10.1093/oep/52.1.3

[10] Linzert, T. (2001) Sources of German Unemployment: Evidence from a Structural VAR Model. SSRN Electronic Journal, 224, 317-336.

[11] Fabiani, S., Locarno, A., Oneto, G. and Sestito, P. (2000) The Sources of Unemployment Fluctuations: An Empirical Application to the Italian Case. ECB Working Paper, Series No. 29.

[12] Gambetti, L. and Pistoresi, B. (2004) Policy Matters. The Long Run Effects of Aggregate Demand and Mark-Up Shocks on the Italian Unemployment. Empirical Economics, 29, 209-226. https://doi.org/10.1007/s00181-003-0159-3

[13] Maidorn, S. (2003) The Effects of Shocks on the Austrian Unemployment Rate-A Structural VAR Approach. Empirical Economics, 28, 387-402. https://doi.org/10.1007/s001810200137

[14] Reichenbachas, T. (2015) Analysis of the Development of the Unemployment Rate in Lithuania: Application of the SVAR Model. Ekonomika, 94, 86. https://doi.org/10.15388/Ekon.2015.3.8789

[15] Davidescu, A.A. (2014) Investigating the Impact of Unemployment Rate on the Romanian Shadow Economy: A Complex Approach Based on ARDL and SVAR Analysis Romanian. Journal of Economic Forecasting, 17, 109-127.

[16] Jacobson, T., Vredin, A. and Warne, A. (1997) Common Trends and Hysteresis in Scandinavian Unemployment. European Economic Review, 41, 1781-1816. https://doi.org/10.1016/S0014-2921(96)00027-X

[17] Algan, Y.P.C. and André, Z. (2002) Public Employment and Labour Market Performance. Economic Policy, 17, 7-66. https://doi.org/10.1111/1468-0327.00083

[18] Christoffel, K.P. and Linzert, T. (2005) The Role of Real Wage Rigidity and Labour Market Frictions for Unemployment and Inflation Dynamics. European Central Bank Working Paper 556.

[19] Karanassou, M. and Sala, H. (2012) Productivity Growth and the Phillips Curve: A Reassessment of the US Experience. Bulletin of Economic Research, 64, 344-366. https://doi.org/10.1111/j.1467-8586.2010.00361.x

[20] Khumalo, Z.Z. (2014) The Determinants of Unemployment in Swaziland: An Econometric Perspective and Investigative Analysis. Doctoral Dissertation.

[21] Eita, J.H. and Ashipala, J.M. (2010) Determinants of Unemployment in Namibia. International Journal of Business and Management, 5, 92-104.

[22] Burger, R. and Fintel, D.V. (2009) Determining the Causes of the Rising South African Unemployment Rate-An Age, Period and Generational Analysis. Stellenbosch Economic Working Papers 24/09.

[23] Banda, H., Ngirande, H. and Hogwe, F. (2016) The Impact of Economic Growth on Unemployment in South Africa: 1994-2012. Investment Management and Financial Innovations, 13, 246-255. https://doi.org/10.21511/imfi.13(2-1).2016.11

[24] Smit, P.C., Mostert, J.W. and Oosthuizen, A.G. (2006) Economics: A South African Perspective. Juta and Co. Ltd.

[25] Sims, C.A., Stock, J.H. and Watson, M.W. (1990) Inference in Linear Time Series Models with Some Unit Roots. Econometrica: Journal of the Econometric Society, 58, 113-144. https://doi.org/10.2307/2938337

[26] Sunde, T. (2015) The Effects of Monetary Policy on Unemployment in Namibia. Journal of Economic and Social Thought, 2, 256-274.

[27] Sunde, T. and Akanbi, O.A. (2016) Sources of Unemployment in Namibia: An Ap- 
plication of the Structural VAR Approach. International Journal of Sustainable Economy, 8, 125-143. https://doi.org/10.1504/IJSE.2016.075917

[28] Chow, G.C. and Lin, A.L. (1971) Best Linear Unbiased Interpolation, Distribution, and Extrapolation of Time Series by Related Series. The Review of Economics and Statistics, 53, 372-375. https://doi.org/10.2307/1928739

[29] Tsonis, A.A. and Austin, G.L. (1981) An Evaluation of Extrapolation Techniques for the Short Term Prediction of Rain Amounts. Atmosphere-Ocean, 19, 54-65. https://doi.org/10.1080/07055900.1981.9649100

[30] Smith, S.K. (1987) Tests of Forecast Accuracy and Bias for County Population Projections. Journal of the American Statistical Association, 82, 991-1003. https://doi.org/10.1080/01621459.1987.10478528

[31] Smith, S.K. and Sincich, T. (1988) Stability over Time in the Distribution of Population Forecast Errors. Demography, 25, 461-474. https://doi.org/10.2307/2061544

[32] Chang, C.C., Chung, S.L. and Stapleton, R.C. (2007) Richardson Extrapolation Techniques for the Pricing of American Style Options. Journal of Futures Markets, 27, 791-817. https://doi.org/10.1002/fut.20272

[33] Gil, A.R. (2012) Causes of Unemployment and the Effectiveness of Demand Policies. Doctoral Dissertation, Leeds University, Leeds.

[34] Akanbi, O.A. and Du Toit, C.B. (2011) Macro-Econometric Modelling for the Nigerian Economy: A Growth-Poverty Gap Analysis. Economic Modelling, 28, 335-350. https://doi.org/10.1016/j.econmod.2010.08.015

[35] Giannini, C. (1991) Topics in Structural VAR Econometrics. Universitadegli Studi di Ancono, Dipartimento di Economia.

[36] Clarida, R. (2001) The Empirics of Monetary Policy Rules in Open Economies. No. w8603, National Bureau of Economic Research. https://doi.org/10.3386/w8603

[37] Lütkepohl, H. (2011) Vector Autoregressive Models. Springer, Berlin Heidelberg, 1645-1647. https://doi.org/10.1007/978-3-642-04898-2_609

[38] Ravnik, R. and Žilić, I. (2011) The Use of SVAR Analysis in Determining the Effects of Fiscal Shocks in Croatia. Financial Theory and Practice, 35, 25-58.

[39] Kofi Ocran, M. (2011) Fiscal Policy and Economic Growth in South Africa. Journal of Economic Studies, 38, 604-618. https://doi.org/10.1108/01443581111161841

[40] Kilian, L. (2011) Structural Vector Autoregressions. In: Handbook of Research Methods and Applications on Empirical Macroeconomics, Edward Elgar Publishing, Cheltenham, 515-554.

[41] Nikolaychuk, S. and Shapovalenko, N. (2014) The Identification of the Sources of Current Account Fluctuations in Ukraine. The Herald of the National Bank of Ukraine, No. 2, 20-27.

[42] Dickey, D.A. and Fuller, W.A. (1979) Distribution of the Estimators for Autoregressive Time Series with a Unit Root. Journal of the American Statistical Association, 74, 427-431. https://doi.org/10.1080/01621459.1979.10482531

[43] Dickey, D.A. and Fuller, W.A. (1981) Likelihood Ratio Statistics for Autoregressive Time Series with a Unit Root. Econometrica: Journal of the Econometric Society, 49, 1057-1072. https://doi.org/10.2307/1912517

[44] Phillips, P.C. and Perron, P. (1988) Testing for a Unit Root in Time Series Regression. Biometrika, 75, 335-346. https://doi.org/10.1093/biomet/75.2.335

[45] Hamilton, D.J. (1994) Time Series Analysis. Princeton University Press, Princeton.

[46] Berkelmans, L. (2005) Credit and Monetary Policy: An Australian SVAR. Reserve 
Bank of Australia Canberra, ACT, 1-32.

[47] Alom, F., Ward, B.D. and Hu, B. (2013) Macroeconomic Effects of World Oil and Food Price Shocks in Asia and Pacific Economies: Application of SVAR Models. OPEC Energy Review, 37, 327-372. https://doi.org/10.1111/opec.12015

[48] Khan, M. and Ahmed, A. (2014) Revisiting the Macroeconomic Effects of Oil and Food Price Shocks to Pakistan Economy: A Structural Vector Autoregressive (SVAR) Analysis. OPEC Energy Review, 38, 184-215. https://doi.org/10.1111/opec.12020

[49] Khan, M.A. and Ahmed, A. (2011) Macroeconomic Effects of Global Food and Oil Price Shocks to the Pakistan Economy: A Structural Vector Autoregressive (SVAR) Analysis. The Pakistan Development Review, 50, 491-511.

[50] Sims, C.A. (1980) Macroeconomics and Reality. Econometrica: Journal of the Econometric Society, 48, 1-48. https://doi.org/10.2307/1912017

[51] Enders, W. (2008) Applied Econometric Time Series. John Wiley \& Sons, Hoboken.

[52] Bernanke, B.S. and Mihov, I. (1998) Measuring Monetary Policy. The Quarterly Journal of Economics, 113, 869-902. https://doi.org/10.1162/003355398555775

[53] Bernanke, B.S. (1986) Alternative Explanations of the Money-Income Correlation. Carnegie-Rochester Conference Series on Public Policy, 25, 49-99.

https://doi.org/10.3386/w1842

[54] Perotti, R. (2002) Estimating the Effects of Fiscal Policy in OECD Countries. European Central Bank, Working Paper No. 168.

[55] Jacobs, J.P. and Wallis, K.F. (2005) Comparing SVARs and SEMs: Two Models of the UK Economy. Journal of Applied Econometrics, 20, 209-228. https://doi.org/10.1002/jae.839

[56] Sonedda, D. (2006) A Structural VAR Approach on Labour Taxation Policies. Applied Economics, 38, 95-114. https://doi.org/10.1080/00036840500166415

[57] Heppke-Falk, K.H., Tenhofen, J. and Wolf, G.B. (2006) The Macroeconomic Effects of Exogenous Fiscal Policy Shocks in Germany: A Disaggregated SVAR Analysis. Deutsche Bundesbank Discussion Paper Series 1: Economic Studies, No. 41/2006. http://econstor.eu/bitstream/10419/19670/1/200641dkp.pdf

[58] Bhuiyan, R. (2008) Monetary Transmission Mechanism in a Small Open Economy: A Bayesian Structural VAR Approach. No. 1183, Queen's Economics Department Working Paper.

[59] Dungey, M. and Pagan, A. (2009) Extending a SVAR Model of the Australian Economy. Economic Record, 85, 1-20. https://doi.org/10.1111/j.1475-4932.2008.00525.x

[60] Ngalawa, H. and Viegi, N. (2011) Dynamic Effects of Monetary Policy Shocks in Malawi. South African Journal of Economics, 79, 224-250. https://doi.org/10.1111/j.1813-6982.2011.01284.x

[61] Parrado, E. (2001) Effects of Foreign and Domestic Monetary Policy in a Small Open Economy: The Case of Chile. Working Paper No. 108, Banco Central de Chile.

[62] Giordano, R., Momigliano, S., Neri, S. and Perotti, R. (2007) The Effects of Fiscal Policy in Italy: Evidence from a VAR Model. European Journal of Political Economy, 23, 707-733. https://doi.org/10.1016/j.ejpoleco.2006.10.005

[63] Dolado, J.J. and Jimeno, J.F. (1997) The Causes of Spanish Unemployment: A Structural VAR Approach. European Economic Review, 41, 1281-1307. https://doi.org/10.1016/S0014-2921(97)00058-5 
[64] Carstensen, K. and Hansen, G. (2000) Cointegration and Common Trends on the West German Labour Market. Empirical Economics, 25, 475-493. https://doi.org/10.1007/s001810000028

[65] Chuku, C., Effiong, E. and Sam, N. (2010) Oil Price Distortion and Their Short-Run and Long-Run Impacts on the Nigerian Economy. MPRA Paper 24434, 1-30.

[66] Burbidge, J. and Harrison, A. (1985) An Historical Decomposition of the Great Depression to Determine the Role of Money. Journal of Monetary Economics, 16, 45-54. https://doi.org/10.1016/0304-3932(85)90005-4

[67] Christiano, L.J., Eichenbaum, M. and Evans, C.L. (1999) Monetary Policy Shocks: What Have We Learned and to What End? Handbook of Macroeconomics, 1, 65-148. https://doi.org/10.1016/S1574-0048(99)01005-8 


\section{Appendix}

Table A1. Percentage distribution of employed population by age group and occupation 2014/2015.

\begin{tabular}{|c|c|c|c|c|c|c|c|c|c|c|c|}
\hline $\begin{array}{l}\text { Age } \\
\text { group }\end{array}$ & $\begin{array}{c}\text { Armed } \\
\text { forces } \\
\text { occupations }\end{array}$ & Managers & Professionals & $\begin{array}{l}\text { Technicians } \\
\text { s and associate } \\
\text { professionals }\end{array}$ & $\begin{array}{l}\text { Clerical } \\
\text { support } \\
\text { workers }\end{array}$ & $\begin{array}{c}\text { Service } \\
\text { and sales } \\
\text { workers }\end{array}$ & $\begin{array}{c}\text { Skilled } \\
\text { agriculture, } \\
\text { forestry and } \\
\text { fishery } \\
\text { worker }\end{array}$ & $\begin{array}{l}\text { Craft and } \\
\text { related } \\
\text { trades } \\
\text { workers }\end{array}$ & $\begin{array}{l}\text { Plant and } \\
\text { machine } \\
\text { operators, } \\
\text { and } \\
\text { assemblers }\end{array}$ & $\begin{array}{l}\text { Elementary } \\
\text { occupations }\end{array}$ & Total \\
\hline $15-19$ & 0.0 & 0.0 & 0.0 & 1.1 & 0.0 & 1.8 & 3.4 & 0.9 & 1.4 & 10.1 & 5.1 \\
\hline $20-24$ & 0.0 & 0.0 & 5.9 & 4.6 & 13.0 & 14.0 & 7.4 & 7.9 & 5.2 & 16.5 & 11.5 \\
\hline $25-29$ & 7.2 & 8.1 & 14.8 & 9.7 & 32.0 & 18.5 & 8.1 & 18.7 & 15.0 & 13.9 & 14.1 \\
\hline $30-34$ & 25.8 & 11.8 & 21.5 & 23.2 & 14.8 & 18.7 & 10. & 19.1 & 22.4 & 13.7 & 15.5 \\
\hline $35-39$ & 36.2 & 12.8 & 16.0 & 14.9 & 12.8 & 15.4 & 8.4 & 18.9 & 17.4 & 11.9 & 13.1 \\
\hline $40-44$ & 0.0 & 11.5 & 7.8 & 10.0 & 11.2 & 11.1 & 7.6 & 11.6 & 17.8 & 9.3 & 9.8 \\
\hline $45-49$ & 2.8 & 16.6 & 10.2 & 12.4 & 5.1 & 6.9 & 6.2 & 9.0 & 8.3 & 6.9 & 7.6 \\
\hline $50-54$ & 23.6 & 8.8 & 8.8 & 15.8 & 5.6 & 4.0 & 9.1 & 5.5 & 5.6 & 6.7 & 7.1 \\
\hline $55-59$ & 0.0 & 7.2 & 6.8 & 1.2 & 2.3 & 4.1 & 8.1 & 4.6 & 4.9 & 4.9 & 5.4 \\
\hline $60-64$ & 0.0 & 4.5 & 3.5 & 3.4 & 2.5 & 2.5 & 11.3 & 1.3 & 1.8 & 2.5 & 4.1 \\
\hline $65+$ & 4.5 & 18.7 & 4.8 & 3.7 & 0.8 & 3.2 & 19.8 & 2.5 & 0.4 & 3.5 & 6.5 \\
\hline Total (\%) & 100.0 & 100.0 & 100.0 & 100.0 & 100.0 & 100.0 & 100.0 & 100.0 & 100.0 & 100.0 & 100.0 \\
\hline Total (N) & 2706 & 15,650 & 60,073 & 19,868 & 16,894 & 82,789 & 132,481 & 70,902 & 34,076 & 293,980 & 729,418 \\
\hline
\end{tabular}

Source: [5].

Table A2. Description of the variables and data sources.

\begin{tabular}{|c|c|c|c|}
\hline Variable Name & Acronym & Variable Explanation & Data Source \\
\hline Total Labour Force & $L F C$ & $\begin{array}{l}\text { Due to lack of data on the labour force for the period } 1980 \text { to 1989, the main } \\
\text { method used to generate the values for the labour force for the period } 1980 \text { to } 1989 \\
\text { is the backward extrapolation technique similar to that used by Smith and Sincich } \\
\text { (1988), Chow and Lin (1971), Smith (1987), Chang et al. (2007), Tsonis and Austin } \\
\text { (1981) and Sunde and Akanbi, (2016). }\end{array}$ & $\begin{array}{l}\text { World Bank-World } \\
\text { Development Indicators } \\
\text { and author calculations }\end{array}$ \\
\hline Unemployment & $U E M$ & $\begin{array}{l}\text { Due to lack of data on the labour force for the period } 1980 \text { to 1989, the main } \\
\text { method used to generate the values for the labour force for the period } 1980 \text { to } 1989 \\
\text { is the backward extrapolation technique similar to that used by Smith and Sincich } \\
\text { (1988), Chow and Lin (1971), Smith (1987), Chang et al. (2007), Tsonis and Austin } \\
\text { (1981) and Sunde and Akanbi, (2016). }\end{array}$ & $\begin{array}{l}\text { World Bank-World } \\
\text { Development Indicators } \\
\text { and author calculations }\end{array}$ \\
\hline Employment & $E M P$ & Total employment is equivalent to total labour force minus total unemployment. & $\begin{array}{l}\text { World Bank-World } \\
\text { Development Indicators } \\
\text { and author calculations }\end{array}$ \\
\hline $\begin{array}{c}\text { Gross Fixed Capital } \\
\text { Formation }\end{array}$ & $G F C F$ & Gross fixed capital formation as a percent of GDP & SADC \\
\hline $\begin{array}{c}\text { Real Gross Domestic } \\
\text { Product }\end{array}$ & $G D P$ & GDP in constant local currency & $\begin{array}{c}\text { World Bank-World } \\
\text { Development Indicators }\end{array}$ \\
\hline Lending Rates & $L E R$ & $\begin{array}{l}\text { Lending rate is the bank rate that usually meets the short- and medium-term fi- } \\
\text { nancing needs of the private sector. This rate is normally differentiated according } \\
\text { to creditworthiness of borrowers and objectives of financing. The terms and condi- } \\
\text { tions attached to these rates differ by country, however, limiting their comparabil- } \\
\text { ity. }\end{array}$ & $\begin{array}{l}\text { World Bank-World } \\
\text { Development Indicators }\end{array}$ \\
\hline
\end{tabular}




\section{Continued}

Real Wage

$R W G$

Productivity

Consumer Price Index
Note that capital stock and labour are the major inputs in the production process.

To derive wages, the following identity is used:

$G F C F / G D P+E M P / G D P=G D P / G D P=1$

Thus,

$(G F C F * L E P) / G D P+(E M P * R W G) / G D P=G D P / G D P=1$

Calculated using, $G F C F$

$G F C F \times L E R$ represents the total value of capital in the economy and $E M P \times R W G \quad G D P, E M P$ and $L E R$

represents the total wage bill in the economy.

using indicated formula

This implies that:

$R W G=[1-((G F C F * L E R) / G D P)](G D P / E M P)=[(G D P-G F C F * L E R) / E M P]$

This calculation was used by Akanabi and Du Toit (2011) as well as Sunde and Akanbi, (2016).

$P R D$ This is calculated as the ratio of real GDP over total employment (GDP/EMP)

Calculated using $G D P$ and $E M P$

Consumer price index reflects changes in the cost to the average consumer of acquiring a basket of goods and services that may be fixed or changed at specified

World Bank-World intervals, such as yearly. The Laspeyres formula is generally used. Data are period Development Indicators averages.

Table A3. VAR lag order selection criteria.

\begin{tabular}{ccccccc}
\hline Lag & LogL & LR & FPE & AIC & SC & HQ \\
\hline 0 & -28.56344 & NA & $7.57 \mathrm{e}-06$ & 2.397389 & 2.635282 & 2.470115 \\
1 & 110.6372 & $218.7439^{*}$ & $2.24 \mathrm{e}-09^{*}$ & $-5.759803^{*}$ & $-4.332441^{*}$ & $-5.323444^{*}$ \\
2 & 127.1718 & 20.07765 & $4.96 \mathrm{e}-09$ & -5.155127 & -2.538297 & -4.355136 \\
\hline
\end{tabular}

Where, FPE and AIC represent Final prediction error (FPE) and Akaike information criteria, respectively while SC and HQ represent Schwarz information criterion and Hannan-Quinn information criterion, respectivey.* indicates lag order selected by the criterion.

Table A4. VAR residual serial correlation $1 \mathrm{~m}$ tests.

(a)

\begin{tabular}{ccccccc}
\hline \multicolumn{7}{c}{ Null hypothesis: No serial correlation at lag h } \\
\hline Lag & LRE $^{*}$ stat & df & Prob. & Rao F-stat & df & Prob. \\
1 & 26.81364 & 25 & 0.3653 & 1.092345 & $(25,57.2)$ & 0.3803 \\
2 & 26.04318 & 25 & 0.4053 & 1.054649 & $(25,57.2)$ & 0.4204 \\
\hline
\end{tabular}

(b)

\begin{tabular}{ccccccc}
\hline \multicolumn{7}{c}{ Null hypothesis: No serial correlation at lags 1 to $h$} \\
\hline Lag & LRE $^{\star}$ stat & $\mathrm{df}$ & Prob. & Rao F-stat & $\mathrm{df}$ & Prob. \\
1 & 26.81364 & 25 & 0.3653 & 1.092345 & $(25,57.2)$ & 0.3803 \\
2 & 66.12913 & 50 & 0.0628 & 1.444640 & $(50,49.0)$ & 0.0999 \\
\hline
\end{tabular}

*Edgeworth expansion corrected likelihood ratio statistic.

Table A5. VAR residual heteroskedasticity tests (Levels and Squares).

\begin{tabular}{ccc}
\hline Joint test: & & \\
\hline Chi-sq & df & Prob. \\
\hline
\end{tabular}




\section{Continued}

\begin{tabular}{|c|c|c|c|c|c|}
\hline \multicolumn{6}{|l|}{151.3009} \\
\hline \multicolumn{6}{|c|}{ Individual components: } \\
\hline Dependent & R-squared & $F(10,19)$ & Prob. & Chi-sq(10) & Prob. \\
\hline res $1^{\star}$ res 1 & 0.305484 & 0.835717 & 0.6019 & 9.164515 & 0.5166 \\
\hline res $2{ }^{\star}$ res 2 & 0.497635 & 1.882107 & 0.1131 & 14.92904 & 0.1347 \\
\hline res $3^{\star}$ res 3 & 0.355562 & 1.048307 & 0.4436 & 10.66687 & 0.3841 \\
\hline res $4^{\star}$ res 4 & 0.283983 & 0.753569 & 0.6691 & 8.519492 & 0.5782 \\
\hline res $5^{\star}$ res 5 & 0.554184 & 2.361848 & 0.0513 & 16.62552 & 0.0831 \\
\hline res $2^{\star}$ res 1 & 0.368155 & 1.107068 & 0.4054 & 11.04466 & 0.3540 \\
\hline res $3^{\star}$ res 1 & 0.321211 & 0.899103 & 0.5518 & 9.636337 & 0.4730 \\
\hline res $3^{\star}$ res 2 & 0.434161 & 1.457844 & 0.2299 & 13.02482 & 0.2223 \\
\hline res $4^{\star}$ res 1 & 0.413043 & 1.337036 & 0.2806 & 12.39130 & 0.2597 \\
\hline res $4^{\star}$ res 2 & 0.200030 & 0.475088 & 0.8859 & 6.000889 & 0.8152 \\
\hline res $4^{\star}$ res3 & 0.346609 & 1.007906 & 0.4714 & 10.39826 & 0.4063 \\
\hline res5*res 1 & 0.413937 & 1.341972 & 0.2784 & 12.41811 & 0.2580 \\
\hline res $5^{\star}$ res 2 & 0.508912 & 1.968957 & 0.0978 & 15.26735 & 0.1226 \\
\hline res $5^{\star}$ res3 & 0.449314 & 1.550240 & 0.1971 & 13.47941 & 0.1981 \\
\hline res $5^{\star}$ res 4 & 0.244372 & 0.614464 & 0.7833 & 7.331154 & 0.6939 \\
\hline
\end{tabular}

Table A6. Forecast error variance decomposition of unemployment.

\begin{tabular}{ccccccc}
\hline Period & S.E. & LPRD & LUEMP & LEMP & LRWG & INFL \\
\hline 1 & 0.270769 & 7.207876 & 92.79212 & 0.000000 & 0.000000 & 0.000000 \\
2 & 0.421283 & 16.91439 & 72.17888 & 7.870931 & 0.617690 & 2.418112 \\
3 & 0.427235 & 16.56833 & 64.19303 & 15.92834 & 0.891283 & 2.419025 \\
4 & 0.433974 & 15.15398 & 59.71432 & 21.90117 & 0.979470 & 2.251053 \\
5 & 0.442092 & 14.33803 & 56.49603 & 25.82921 & 0.980523 & 2.356204 \\
6 & 0.451773 & 14.05057 & 54.33130 & 28.08691 & 0.950994 & 2.580218 \\
7 & 0.463003 & 14.04683 & 52.99393 & 29.23345 & 0.928543 & 2.797238 \\
8 & 0.475565 & 14.14646 & 52.23965 & 29.72698 & 0.932432 & 2.954476 \\
9 & 0.489171 & 14.25433 & 51.85371 & 29.87519 & 0.969558 & 3.047207 \\
10 & 0.503517 & 14.33191 & 51.67373 & 29.86461 & 1.039453 & 3.090300 \\
& \multicolumn{7}{c}{ Cholesky Ordering: LPRD LUEM LEMP LRWG INF } & \\
\hline
\end{tabular}


Response to Cholesky One S.D. (d.f. adjusted) Innovations \pm 2 S.E.

Response of LUEM to LPRD

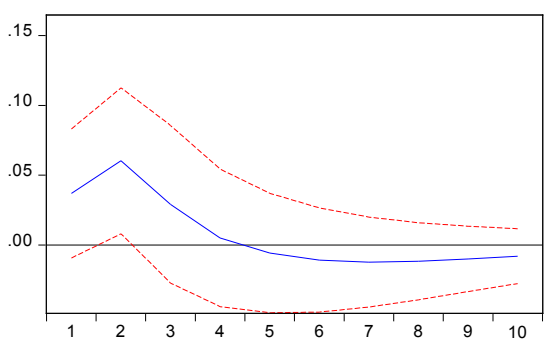

Response of LUEM to LEMP

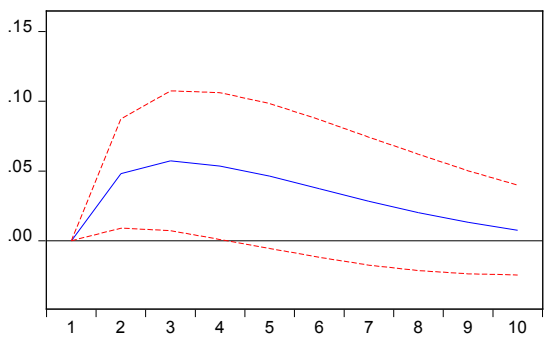

Response of LUEM to INFL

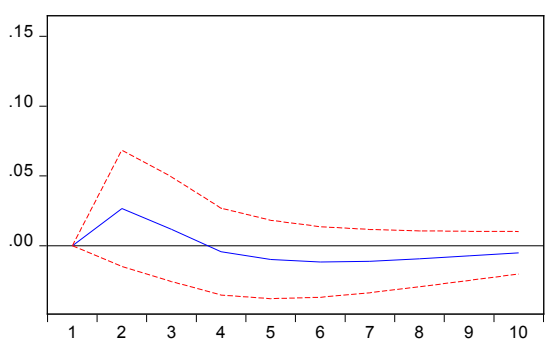

Figure A1. IRFs of the responses of unemployment to shocks in productivity, employment, real wage and inflation.
Response of LUEM to LUEM

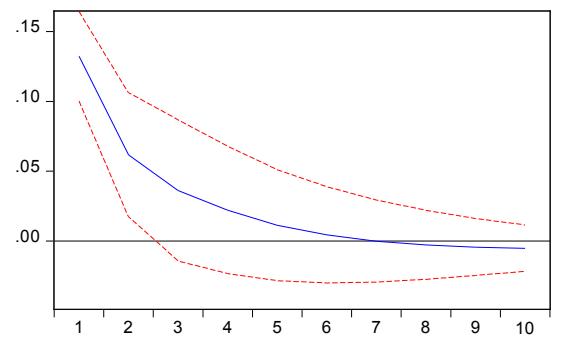

Response of LUEM to LRWG

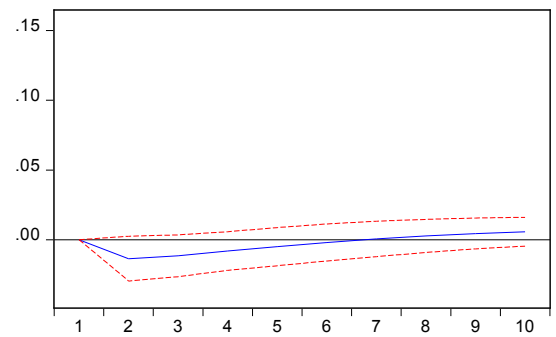

